\title{
Drug combination and nanooncology for improvement in the treatment of breast
}

\section{cancer: a review}

\author{
Combinação de drogas e nanooncologia para melhoria no tratamento do câncer de mama: uma \\ revisão
}

Combinación de fármacos y nanooncología para mejorar el tratamiento del cáncer de mama: una revisión

\begin{abstract}
Optimizing drug combination treatment has been an area of interest for a while, from the beginning with the emergence of the POMP regime. The ability to improve drug combinations for cancer treatment comes up against the possibility of several limitations, such as the lack of specificity of the drugs, generating systemic toxic effects, and also the great possibility of generating tumor cells resistant to the drugs. The development of nanooncology offers advances in new alternatives for the treatment of cancer, especially breast cancer. The strategy of using drugs combined in a nanocarrier for the treatment of breast cancer has proven to be quite effective, taking into account that breast cancer has long shown a good response with therapeutic combinations. In this work, we present a review of some examples of nanoformulations developed with the combination of drugs doxorubicin and/or paclitaxel aimed for the treatment of breast cancer. Also the future perspectives of nanotechnology in the drug combination.
\end{abstract}

Keywords: Breast cancer; Chemotherapy; Nanomedicine; Nanotechnology.

\section{Resumo}

A otimização do tratamento de combinação de medicamentos tem sido uma área de interesse há algum tempo, desde o início com o surgimento do regime POMP. A capacidade de melhorar as combinações de medicamentos para o tratamento do câncer esbarra na possibilidade de várias limitações, como a falta de especificidade dos medicamentos, gerando efeitos tóxicos sistêmicos, e também a grande possibilidade de gerar células tumorais resistentes aos medicamentos. O desenvolvimento da nanooncologia oferece avanços em novas alternativas para o tratamento do câncer, principalmente do câncer de mama. A estratégia de usar medicamentos combinados em um nanocarreador para o tratamento do câncer de mama tem se mostrado bastante eficaz, levando-se em consideração que o câncer de mama há muito apresenta uma boa resposta com combinações terapêuticas. Neste trabalho, apresentamos uma revisão de alguns exemplos de nanoformulações desenvolvidas com a combinação dos fármacos doxorrubicina e / ou paclitaxel voltados para o tratamento do câncer de mama. Também as perspectivas futuras da nanotecnologia na combinação de medicamentos. 
Palavras-chave: Câncer de mama; Quimioterapia; Nanomedicina; Nanotecnologia.

\section{Resumen}

La optimización del tratamiento de combinación de fármacos ha sido un área de interés durante un tiempo, desde el principio con la aparición del régimen POMP. La capacidad de mejorar las combinaciones de fármacos para el tratamiento del cáncer se enfrenta a la posibilidad de varias limitaciones, como la falta de especificidad de los fármacos, que genera efectos tóxicos sistémicos, y también la gran posibilidad de generar células tumorales resistentes a los fármacos. El desarrollo de la nanooncología ofrece avances en nuevas alternativas para el tratamiento del cáncer, especialmente el cáncer de mama. La estrategia de utilizar fármacos combinados en un nanoportador para el tratamiento del cáncer de mama ha demostrado ser bastante eficaz, teniendo en cuenta que el cáncer de mama ha mostrado desde hace mucho tiempo una buena respuesta con combinaciones terapéuticas. En este trabajo presentamos una revisión de algunos ejemplos de nanoformulaciones desarrolladas con la combinación de fármacos doxorrubicina y / o paclitaxel dirigidos al tratamiento del cáncer de mama. También las perspectivas de futuro de la nanotecnología en la combinación de fármacos.

Palabras clave: Cáncer de mama; Quimioterapia; Nanomedicina; Nanotecnología.

\section{Introduction}

Breast cancer is the second most common cancer worldwide and the most frequently diagnosed among women, representing an impact on the quality of life with the therapeutic methods used as, for example, surgery, radiation, immune, stem cell therapy, traditional chemotherapy, and photodynamic. The most popular conventional therapy used to treat many types of cancer, including breast cancer, is chemotherapy with drugs that have positive effects, promoting immune responses against tumors. The drugs used and approved are tamoxifen, methotrexate, docetaxel, doxorubicin (DOX), and paclitaxel (PTX). However, there are challenges in drug delivery limit application: (1) limited aqueous solubility; (2) lack of selectivity of anticancer drugs; (3) multidrug resistance (MDR) (De Cicco et al., 2019; Zeinali et al., 2020).

Oncological therapy, which includes breast cancer therapy, is one of the most studied fields to provide new therapeutic alternatives, including combined drug therapy that has become a standard of care, promoting mainly cost reduction, increased efficacy, and decreased dosage. On the other hand, the combination of two or more drugs, although it may offer therapeutic advantages far more than they would offer alone, it is necessary to consider that there are aspects that can cause complications such as adverse effects that can be aggravated due to simultaneous administration, besides, factors such as differences in pharmacokinetic profiles can limit the efficiency of the therapy (Correia et al., 2018; Shim et al., 2017).

In this sense, nanotechnology has stood out, over the years, as an effective method for the treatment of a variety of cancers, especially breast cancer, offering modern strategies based on nanoparticles, characteristic that gives unique properties, allowing better solubility, biocompatibility, conductivity, reduced toxicity, and multifunctionality, to overcome existing challenges in conventional therapy with the best targeting of drugs in the tumor (Barzaman et al., 2020).

Nanotechnology also offers many advantages for combination drug therapy such as loading capacity, reduced toxicity, stability, efficacy, specificity, and tolerability of drug-loaded nanoparticles (Tran et al., 2020). It's important to highlight this synergistic performance, making the cumulative effect of combination drugs greater than the sum of the individual effects of each (Rajora et al., 2020). Main examples of nanoformulations used in the studies to allow efficient delivery of drug combinations are lipids (solid lipid nanoparticles, nanostructured lipid carriers, liposomes), polymers (polymeric nanoparticles), and inorganic materials (gold nanoparticles). Although there are several promising preclinical and clinical studies involving the approach of nanotechnology and combined therapy, clinical validation is still limited and difficult to achieve (Tran et al., 2020; Ventola, 2017).

In this sense, knowing that there is an exhaustive set of literature available on the drug combination treatment options for different types of cancer, especially breast cancer. In the first part of this review, we discuss the current treatment options using drug combination since the beginning with the POMP regimen, including combination therapy for breast cancer. After that, we 
talked about the development of nanomedicine, more particularly about the nanooncology, including the platform for drug combinations. The future perspectives and the clinical applicability of nanotechnology in the drug combination.

\section{Methodology}

The textual production of this study was developed based on the scientific literature in PubMed, Scielo, and Google Scholar databases. According to the indexes of the various databases, search terms were used: "breast cancer". "chemotherapy", "nanomedicine", "nanotechnology", without any language restrictions.

\section{Clinical Use of Drug Combination in Cancer Therapy}

The beginning of modern chemotherapy is marked by an event called POMP regimen, a combination of methotrexate, vincristine and prednisone. This co-administration has shown to be very promising in the treatment of acute lymphoblastic leukemia because it induces long-term remissions in children undergoing this regimen (Frei III et al., 1965). Thus, it has been proved that the combination of drugs with different sites of action has proven to be very effective in treating cancer, including preventing the emergence of drug resistant tumor cells.

Following the implementation of Cooper regimen (1969) in the treatment of advanced breast cancer, using a combination of cyclophosphamide, methotrexate, 5-FU, vincristine and prednisolone (some or all of this agents) Devita and coauthors (1975) created the MOPP regimen used to treat Hodgkin's and non-Hodgkin's lymphoma. This regimen consists of the combination of nitrogen mustard, vincristine, procarbazine and prednisone. From this point on, the scientific world has seen the promising ability to use combined chemotherapy to improve cancer treatment and even enable healing (Cooper, 1969; Devita Jr et al., 1975).

Thereafter, The National Project of Adjuvant Breast and Intestine Surgery from 1967 to 1994 was marked by the work of Bonadonna et al., 1976. In this study, it was proved that the use of adjuvant chemotherapy using cyclophosphamide, methotrexate, and fluorouracil after complete surgical resection of breast tumors would prolong significantly improved patient survival, especially those with axillary lymph node metastases and a high risk of relapse (Bonadonna et al., 1976). After that, in recent years, a variety of combinations has been tested, and many of these are used in today's clinics according to American cancer society. Co-administration drug therapies have shown positive results for different types of tumors.

The use of combined chemotherapy has become a strategy conventionally applied in clinical practice, thus offering better chances of efficacy and dose reduction, decreased toxicity and reduced or delayed development of drug resistance. Today, some combinations are in place to treat most cancers, especially breast cancer. Such as: The drug combinatorial treatment for stomach cancer mostly involves the ECF regimen (epirubicin, cisplatin, and 5-FU), which may be given before and after surgery. To treat Liver cancer one option is the GEMOX regimen (gemcitabine plus oxaliplatin) for people who are reasonably healthy and may tolerate more than one drug in treatment, and for people with bad liver disease FOLFOX regimen (5-FU, oxaliplatin, and leucovorin), is another option (Fisusi \& Akala, 2019).

Combination chemotherapy for breast cancer can involve 2 or 3 of these drugs: The main classes used are anthracyclines, antimicrotubules (taxanes), alkylating agents (cyclophosphamide), antimetabolites (5-fluorouracil, capecitabine), platinum compounds (cisplatin) among others. And these classes of chemotherapeutic drugs can be combined: CAF/FAC (cyclophosphamide / DOX / 5-fluorouraci (5-FU)), FEC (5-fluorouraci(5-FU) / epirubicin / cyclophosphamide), AC (DOX / cyclophosphamide), EC (epirubicin / cyclophosphamide), CMF (cyclophosphamide / methotrexate / 5-fluorouraci (5-FU)), docetaxel / capecitabine, GT (gemcitabine / PTX), gemcitabine / carboplatin, PTX / bevacizumab. Thus being more effective in treatment due to the possibilities of drug combinations (Al-Mahayri et al., 2020; Fisusi \& Akala, 2019). 
According to Malhotra \& Perry (2003), drugs with different mechanisms of action and different toxicities should be combined to generate additive or synergistic effects with minimal toxicity. Considering the therapeutic window, for a drug to be effective, the drug concentration must be in the appropriate range. Very low levels may not be beneficial, and very high levels increase systemic toxicity without increasing clinical benefit. Drug combination is used in conventional therapy, and provides superior clinical benefit to single drug use, being within the patient-tolerated range of toxicity for each drug, and broad coverage of cell lines in a heterogeneous tumor population, preventing or delaying the development of new drug resistant cell lines (Malhotra \& Perry, 2003).

Chemotherapy is an individual experience, so each person experiences it differently, both physically and emotionally. Some individuals may have few side effects, while for others, the negative impact on the patient's quality of life and family relationships results in a suffering reaction (Espinosa \& Espinosa, 2016). Nausea, vomiting and fatigue are among the main chemotherapy symptoms present in patients with breast cancer. But, there are also cachexia, loss of appetite, fever, sleep disorders, alopecia, diarrhea and anemia (Özdelikara \& Tan, 2017).

Conventional therapies are still essential for treatment, improvements in quality of life and survival of breast cancer patients. However, they have several limitations, such as the lack of specificity of drugs, generating systemic toxic effects, and also the great possibility of generating drug resistant tumor cells (Nguyen et al., 2011). Therefore, new and better approaches are needed to improve the therapeutic effectiveness of anticancer treatment. Among several emerging approaches to cancer therapy, anomedicine has been gaining ground in both cancer detection and treatment (Mignani et al., 2015). Given that, the use of a combination of drugs that have different mechanisms of action without overlapping side effects may benefit from the application of nanomedicine.

\section{Development of the Nanomedicine to Nano-Oncology}

Nanotechnology is not a new field and scientists have been studying nanoscience phenomena for many decades in various fields of science and medicine. This technology provided valuable tools for further development of materials in the nanoscale size range. Thus helping to formalize nanotechnology as a scientific field. Nanomedicine is a new perspective and focuses that nanotechnology offers in the use of nanoscale materials for the medical area, and may help in the monitoring, diagnosis, and treatment of pathologies (Al-Lazikani et al., 2012; Kostarelos, 2006).

The first results related to the development of nanomedicine started at the end of the 1960's. Although, only in the early 2000s, the governmental science and funding organizations assessed the potential opportunities for better healthcare as well as the risk-benefit analysis of nanomedicine. In 2004 the UK Royal Society and Royal Academy of Engineering, Reported nanoscience and nanotechnologies opportunities and uncertainties. They investigated likely developments and investigated whether nanotechnology might raise or is likely to raise new ethical, health, and safety or social issues that are not covered by the regulation (Society, 2004).

Thereby, nano-oncology is based on the principles of using nanoscale materials that can bring pharmacotechnical advantages in drug development by contributing to overall therapeutic activity and safety, as well as the ability to target and increase the concentration of drugs in the pathological region and non-normal tissues. Notably, systemically injected drugs can be improved by taking advantage of the biological system and nanosystem interactions (Figugure 1) (Wolfram \& Ferrari, 2019). 
Figure 1. Comparative of drug combination and drug combination with nanotechnology.

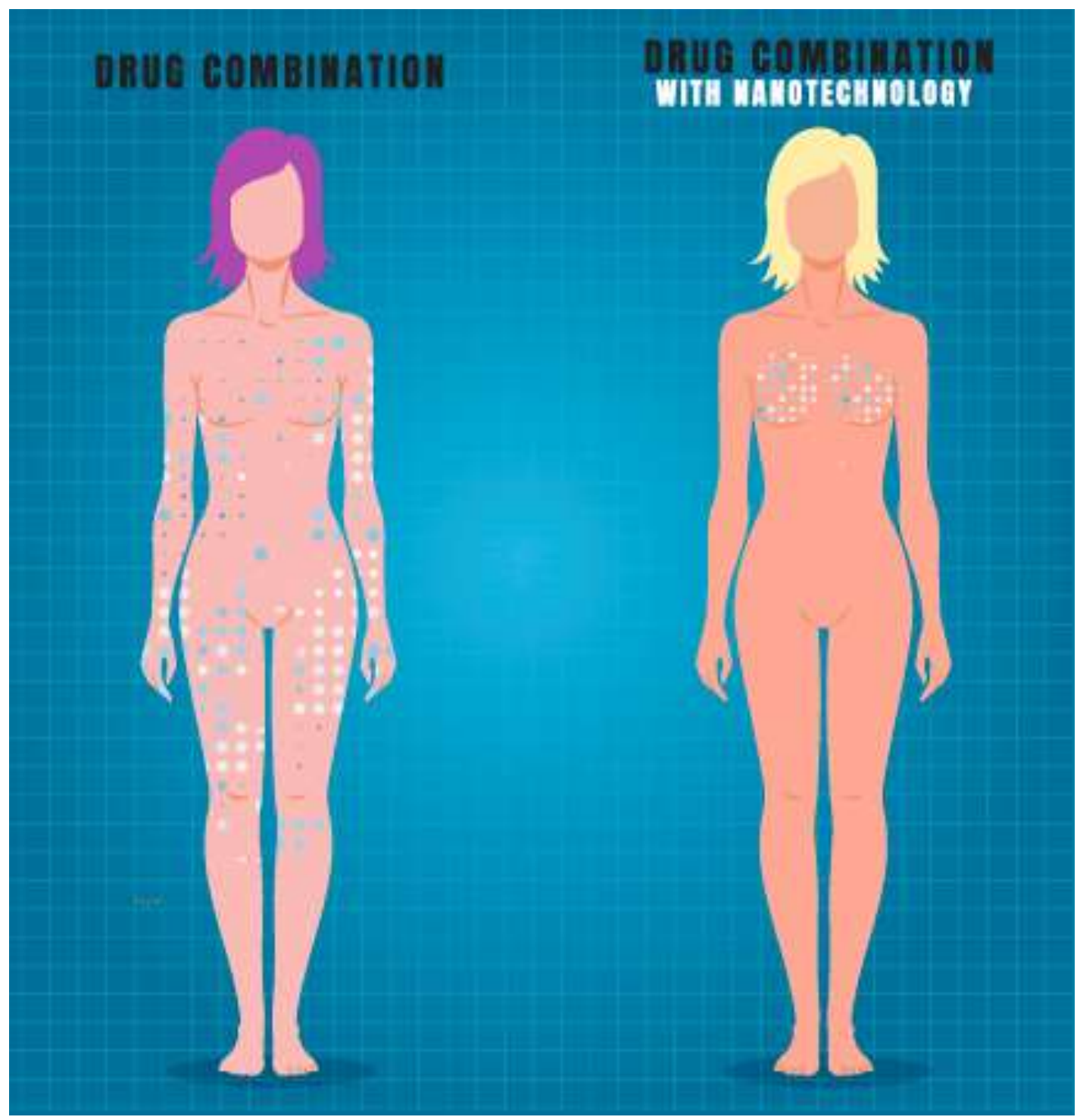

Source: Authors (2021).

Given that, nano-oncology offers an unparalleled opportunity for the development of advanced combined drug delivery strategies, with the ability to improved drug solubility, enhanced pharmacokinetic and pharmacodynamic properties, circulation time prolonged, minimized side effects, and also encapsulate multiple drugs simultaneously and unify the pharmacokinetics of each drug (Al-Lazikani et al., 2012).

\section{Nanotechnology Platform for Drug Combination}

A few decades ago, reaching the stage of commercialization with theranostic nanosystems was only possible for some nanopharmaceuticals. However, the preparation of these nanomaterials that were approved and managed to reach the market, directed the development of more nanostructures for the oncological application, because they brought valuable information that was explored and facilitated the administration and translation of the bench for the diagnosis and treatment of cancer (Li et al., 2018).

DOX is a chemotherapeutic anthracycline, considered the most popular for nanoparticle-mediated delivery for breast cancer and others. DOX is used in combination with other chemotherapeutics, nucleic acids and antibodies in cancer therapy and 
in co-delivery systems based on its antitumor effectiveness. DOX has also been used clinically to treat several hematological malignancies and solid tumors. Other chemotherapeutic agents, such as PTX, cisplatin, trastuzumab, fulvestrant, anastrozole and carboplatin, have been used frequently in phase II and III clinical trials for the treatment of breast cancer. In addition, several combinations of these therapies have synergistic effects in breast carcinomas (Liyanage et al., 2019; Pan et al., 2019).

The use of DOX alone causes serious side effects in normal tissues, especially acute and chronic cardiotoxicity. However, when combined with other chemotherapeutic agents, it obtains a synergistic effect or improves its biodistribution. In the literature, DOX is often combined with PTX. The combination of DOX and PTX encapsulated in polymeric nanoparticles mPEG-PLGA, allowed a better anticancer effect in vivo and a much faster release of the drug carrier in an acidic environment (Liyanage et al., 2019; Pan et al., 2019).

Anthracyclines are important agents in the treatment of metastatic and early breast cancer, but one of its main limitations is cardiotoxicity. Liposomal anthracyclines present highly efficient and effective drug encapsulation, with reduced cardiotoxicity, when compared to conventional anthracyclines. There are several formulations of DOX encapsulated in liposomes available, which have different pharmacological characteristics. The most commonly used are liposomal DOX (Myocet $\left.{ }^{\circledR}\right)$ and pegylated liposomal DOX (Doxil®) (Bulbake et al., 2017).

There are nanopharmaceuticals approved by Food and Drug Administração (FDA) available on the market specially to treat breast cancer and also other different types of cancer. Such as Doxil@ / Caelyx® (PEGylated liposomal of DOX), LipoDox ${ }^{\circledR}$ (pegylated liposomal DOX), Myocet ${ }^{\mathrm{TM}}$ (non-pegylated liposomal DOX), Abraxane ${ }^{\circledR}$ (albumin-bound PTX), Lipusu® (Liposomal PTX), Genexol®PM (PTX-loaded polymeric micelle), and Nanoxel® (mPEG-PDLLA / PTX) (Aulic et al., 2020; Bobo et al., 2016; Di Wu et al., 2017; Falagan-Lotsch et al., 2017; Fraguas-Sánchez et al., 2019; Z. Li et al., 2017) (Table 1). 
Table 1. Approved nanodrugs for use breast cancer treatment.

\begin{tabular}{|c|c|c|c|c|}
\hline Trade name & Type of Nanoformulation & Main features & Approval & Ref. \\
\hline $\begin{array}{l}\text { Doxil (Janssen products)/ } \\
\text { Caelyx }\end{array}$ & Liposome NPs & $\begin{array}{l}\text { Particle size: } 80-90 \mathrm{~nm} \text {. } \\
\text { Formulation: External lipid bilayer- } \\
\text { hydrogenated soy phosphatidylcholine, } \\
\text { cholesterol and PEG-modified } \\
\text { phosphatidyl-ethanolamine. } \\
\begin{array}{l}\text { Doxorubicin-encapsulated in the } \\
\text { aqueous nucleus. }\end{array}\end{array}$ & 1995 & $\begin{array}{l}\text { (Aulic et al., 2020; } \\
\text { Fraguas-Sánchez et al., } \\
\text { 2019) }\end{array}$ \\
\hline $\begin{array}{c}\text { Lipodox (Sun Pharma Global } \\
\text { FZE) }\end{array}$ & Liposome NPs & Considered generic of Doxil. & 2013 & (Aulic et al., 2020) \\
\hline $\begin{array}{l}\text { Myocet (Sopherion } \\
\text { Therapeutics) }\end{array}$ & Liposome NPs & $\begin{array}{l}\text { Particle size: } 190 \mathrm{~nm} \text {. } \\
\text { Formulation: lamellar vesicles-lipid } \\
\text { bilayer is formed by phosphatidylcholine } \\
\text { and cholesterol. }\end{array}$ & 2000 & $\begin{array}{l}\text { (Aulic et al., 2020; } \\
\text { Fraguas-Sánchez et al., } \\
\text { 2019) }\end{array}$ \\
\hline Abraxane (nab-PTX) & Protein NPs & $\begin{array}{l}\text { Particle size: } 130 \mathrm{~nm} \text {. } \\
\text { Formulation: Cremophor-EL free } \\
\text { nanoformulation-albumin nanoparticles } \\
\text { as paclitaxel carrier. }\end{array}$ & 2005 & $\begin{array}{l}\text { (Aulic et al., 2020; } \\
\text { Fraguas-Sánchez et al., } \\
\text { 2019) }\end{array}$ \\
\hline $\begin{array}{c}\text { Lipusu (Sike Pharmaceutical } \\
\text { Co. Ltd) }\end{array}$ & Liposome NPs & $\begin{array}{l}\text { Particle size: } 400 \mathrm{~nm} \text {. } \\
\text { Formulation: Lipid bilayer is formed } \\
\text { phosphatidylcholine and cholesterol with } \\
\text { PTX carrier. }\end{array}$ & 2006 & $\begin{array}{l}\text { (Aulic et al., 2020; } \\
\text { Fraguas-Sánchez et al., } \\
\text { 2019) }\end{array}$ \\
\hline $\begin{array}{c}\text { Genexol-PM (Samyang } \\
\text { Biopharm) }\end{array}$ & Polymeric NPs & $\begin{array}{l}\text { Particle size: } 20-50 \mathrm{~nm} \text {. } \\
\text { Formulation: polymeric micellar PTX } \\
\text { formed by monomethoxy-poly di-block } \\
\text { copolymer and which lacks Cremophor- } \\
\text { EL as a solubilizing PTX. }\end{array}$ & 2007 & $\begin{array}{l}\text { (Aulic et al., 2020; } \\
\text { Fraguas-Sánchez et al., } \\
\text { 2019) }\end{array}$ \\
\hline $\begin{array}{c}\text { Nanoxel (Fresenius Kabi India } \\
\text { Pvt Ltd) }\end{array}$ & Polymeric NPs & $\begin{array}{l}\text { Particle size: } 80-100 \mathrm{~nm} \text {. } \\
\text { Formulation: polymeric micelles- } \\
\text { copolymer of N-isopropyl acrylamide } \\
\text { and pH sensitive vinylpyrrolidone } \\
\text { monomers. }\end{array}$ & 2006, phase I in India & $\begin{array}{l}\text { (Aulic et al., 2020; } \\
\text { Fraguas-Sánchez et al., } \\
\text { 2019) }\end{array}$ \\
\hline
\end{tabular}


Different formulations have been developed for the purpose of drug co-encapsulation, and in 2017 the FDA approved the first liposomal formulation with co-encapsulated drugs. Vyxeos ${ }^{\mathrm{TM}}$ (CPX-351) is a nanoformulation using combined chemotherapy. It is a liposomal formulation of the combination of cytarabine and daunorubicin (5: 1 molar ratio, respectively) approved for the treatment of adults with newly diagnosed therapy-related acute myeloid leukemia (t-AML) or acute myeloid leukemia (AML) with myelodysplasia-related changes (AML-MRC). Vyxeos ${ }^{\mathrm{TM}}$ exhibited increased synergistic activity in both cell cultures and animal studies. Another important finding of Vyxeos ${ }^{\mathrm{TM}}$ is related to overall survival, with an increase in survival to 9.56 months compared to 5.95 months in patients treated with a combination of free cytarabine and daunorubicin (standard treatment) (Beltrán-Gracia et al., 2019).

The release of liposome-based drugs is capable of modifying the pharmacokinetics and pharmacodynamics of cytostatic agents, thus increasing the concentration of the drug released in the neoplastic tissue. Phospholipids are the main components of liposomes, which makes them less toxic and non-immunogenic, biodegradable and biocompatible. The phospholipid bilayer prevents the active form of the drug from decomposing before reaching the tumor tissue, minimizing the exposure of normal tissue to the drug. Liposomal formulations have an additional effect on the drug's metabolism, decreasing its enzymatic degradation (Bulbake et al., 2017)

The drug combination strategy goes through experimental steps in vivo and in vitro that are challenging because they include the need to optimize cytotoxicity, not only of the drug, but of the drug interactions, pharmacokinetics and antitumor activity. Studies carried out on the use of nanotechnology have achieved satisfactory results and it is expected that they will advance to the clinical phase, making it possible later on to introduce them into therapeutic practice and commercialization (Wu et al., 2020).

There are already also some nanoformulation combination treatments that are used to treat breast cancer, taking into account that breast cancer has long demonstrated a good response with therapeutic combinations (Devita Jr et al., 1975). Some of the platforms are: Liposomes (DOX for chemotherapy; chloroquine as autophagy inhibitor), PLGA-PEG nanoparticle (Rapamycin as chemotherapy agent; piperine as chemosensitizer, or DOX for chemotherapy; resveratrol to help), Folateconjugated lipid nanoparticles (PTX for chemotherapy; curcumin or DOX for chemotherapy; pTRAIL as chemosensitizer) (Di Wu et al., 2017).

In this study, we try to briefly explain some examples of nanoformulations, based on lipid, polymer and inorganic, developed with the combination of drugs, generally used DOX and/or PTX, aimed at breast cancer in the preclinical / clinical phase (Table 2). 
Table 2. Examples of nanoformulations prepared with drug combinations DOX and/or PTX for breast cancer in preclinical/clinical phase.

\begin{tabular}{|c|c|c|c|c|}
\hline $\begin{array}{l}\text { Nanoplatform/ } \\
\text { Nanoformulation }\end{array}$ & Combination drugs & Status & Outcomes & Ref. \\
\hline \multicolumn{5}{|l|}{ LIPID-BASED } \\
\hline $\begin{array}{l}\text { Nanoparticle albumin-bound } \\
\text { paclitaxel / nonpegylated } \\
\text { liposome-encapsulated } \\
\text { doxorubicin combination } \\
\text { (wNP/wNPLD) }\end{array}$ & $\begin{array}{c}\text { Paclitaxel (PTX) + } \\
\text { Doxorubicin (DOX) }\end{array}$ & $\begin{array}{l}\text { Clinical trials: Phase I } \\
\text { Population: } 12 \text { patients (mean age: } 52 \\
\text { years; median metastatic sites: 2). } \\
\text { Metastatic breast cancer patients naive } \\
\text { to previous chemotherapy for advanced } \\
\text { disease. }\end{array}$ & $\begin{array}{l}\text { wNP/wNPLD } \\
\text { constitutes an active regimen with } \\
\text { mild toxicity. }\end{array}$ & (Fabi et al., 2020) \\
\hline $\begin{array}{l}\text { Estrone-targeted PEGylated } \\
\text { epirubicin and paclitaxel co- } \\
\text { loaded liposomal nanoparticle } \\
\text { (ES-SSL-EPI/PTX) }\end{array}$ & Epirubicin $(\mathrm{EPI})+\mathrm{PTX}$ & Preclinical & $\begin{array}{l}\text { In vitro: effective cytotoxic activity } \\
\text { in human breast cancer MCF- } 7 \text { cells; } \\
\text { In vivo: significantly suppressed } \\
\text { tumor growth in the MCF-7-derived } \\
\text { tumor-bearing mouse model without } \\
\text { inducing toxicity. }\end{array}$ & (Tang et al., 2020) \\
\hline $\begin{array}{l}\text { Long-circulating and fusogenic } \\
\text { liposomes co-encapsulating } \\
\text { doxorubicin and paclitaxel } \\
\text { (LCFL-PTX/DXR) }\end{array}$ & PTX + DOX & Preclinical & $\begin{array}{l}\text { In vitro: better antitumor efficacy. } \\
\text { Low cytotoxicity in } 4 \mathrm{~T} 1 \text { cells; } \\
\text { In vivo: improved cardiac toxicity } \\
\text { profile. }\end{array}$ & (Franco et al., 2019) \\
\hline $\begin{array}{l}\text { Long-circulating and fusogenic } \\
\text { liposomes co-encapsulating } \\
\text { doxorubicin and paclitaxel } \\
\text { (LCFL-PTX/DXR) }\end{array}$ & PTX + DOX & Preclinical & $\begin{array}{l}\text { In vitro: low cytotoxicity in } 4 \mathrm{~T} 1 \text { cells } \\
\text { and efficient synergism between } \\
\text { drugs. }\end{array}$ & (Roque et al., 2019) \\
\hline $\begin{array}{l}\text { Doxorubicin and paclitaxel co- } \\
\text { loaded liposomal delivery } \\
\text { system modified with an acid- } \\
\text { cleavable cholesterol- } \\
\text { hyaluronic acid conjugate } \\
\text { (Chol-HA) } \\
\text { (HA-D/P-Lip) }\end{array}$ & PTX + DOX & Preclinical & $\begin{array}{l}\text { In vitro: superior cytotoxicity in } \\
\text { MCF-7 breast cancer cells and } \\
\text { synergistic effect. Higher cell } \\
\text { internalization. }\end{array}$ & (Song et al., 2019) \\
\hline
\end{tabular}


Table 2 Cont. Examples of nanoformulations prepared with drug combinations DOX and/or PTX for breast cancer in preclinical/clinical phase.

\begin{tabular}{|c|c|c|c|c|}
\hline $\begin{array}{l}\text { Nanoplatform/ } \\
\text { Nanoformulation }\end{array}$ & Combination drugs & Status & Outcomes & Ref. \\
\hline \multicolumn{5}{|l|}{ LIPID-BASED } \\
\hline $\begin{array}{c}\text { Doxorubicin and cisplatin } \\
\text { loaded nanostructured lipid } \\
\text { carriers } \\
\text { (D-C-NLCs) }\end{array}$ & Doxorubicin (DOX) + Cisplatin (CDDP) & Preclinical & $\begin{array}{l}\text { In vitro: highest cytotoxicity and } \\
\text { synergistic effect of two drugs in tumor } \\
\text { cells (MCF-7/ADR cells); } \\
\text { In vivo: greatest anti-tumor activity } \\
\text { than the other formulations in the breast } \\
\text { cancer model. }\end{array}$ & (Di et al., 2016) \\
\hline $\begin{array}{c}\text { Cyclic RGD } \\
\text { (arginylglycylaspartic acid) } \\
\text { peptide introduced to the } \\
\text { surface of } \\
\text { lipid/calcium/phosphate } \\
\text { asymmetric lipid layer } \\
\text { nanoparticles for the co-delivery } \\
\text { of paclitaxel and gemcitabine } \\
\text { monophosphate } \\
\text { (P/G-NPs) }\end{array}$ & $\begin{array}{l}\text { Paclitaxel }(\mathrm{PTX})+\text { Gemcitabine } \\
\text { monophosphate (GMP) }\end{array}$ & Preclinical & $\begin{array}{l}\text { In vitro: cellular uptake, longer } \\
\text { circulation lifetime and improved } \\
\text { absorption for PTX and GMP. } \\
\text { In vivo: enhanced the drug } \\
\text { accumulation in tumors. P/G-NPs } \\
\text { nearly halted tumor growth, with little } \\
\text { evidence of general toxicity. }\end{array}$ & (Zhang et al., 2018) \\
\hline $\begin{array}{l}\text { Nanostructed lipid carriers } \\
\text { loaded with alpha-tocopherol } \\
\text { succinate and doxorubicin } \\
\text { (NLC-TS-DOX) }\end{array}$ & Alpha - tocopherol succinate $(\mathrm{TS})+\mathrm{DOX}$ & Preclinical & $\begin{array}{l}\text { In vitro: synergic combination between } \\
\text { DOX and TS. } \\
\text { In vivo: favorable pharmacokinetic and } \\
\text { antitumor activity. }\end{array}$ & (Fernandes et al., 2018) \\
\hline \multicolumn{5}{|l|}{ INORGANIC-BASED } \\
\hline $\begin{array}{c}\text { Polydopamine (PDA)-coated Au } \\
\text { nanostar (NS@PPFA) }\end{array}$ & DOX + Dopamine & Preclinical & $\begin{array}{l}\text { In vitro: specific cellular uptake and } \\
\text { cytotoxicity; } \\
\text { In vivo: anticancer and antiangiogenic } \\
\text { activities. }\end{array}$ & (You et al., 2019) \\
\hline
\end{tabular}


Table 2 Cont. Examples of nanoformulations prepared with drug combinations DOX and/or PTX for breast cancer in preclinical/clinical phase.

\begin{tabular}{|c|c|c|c|c|}
\hline $\begin{array}{l}\text { Nanoplatform/ } \\
\text { Nanoformulation }\end{array}$ & Combination drugs & Status & Outcomes & Ref. \\
\hline \multicolumn{5}{|l|}{ POLYMER-BASED } \\
\hline $\begin{array}{c}\text { Polymer-dopamine } \\
\text { nanocomposite constructed for } \\
\text { co-encapsulation of doxorubicin } \\
\text { and paclitaxel, and absorption } \\
\text { of small interfering RNAs } \\
\text { against survivin } \\
\text { (NP-DTS-PDA) }\end{array}$ & Doxorubicin $(\mathrm{DOX})+$ Paclitaxel $(P T X)$ & Preclinical & $\begin{array}{l}\text { In vitro: NP-DTS-PDA can be taken } \\
\text { up by cancer cells, induce effective } \\
\text { combination therapy, and sensitize } \\
\text { cancer cells; } \\
\text { In vivo: tumor regression and even } \\
\text { eradication. }\end{array}$ & (Ding et al., 2017) \\
\hline $\begin{array}{l}\text { Polyethylene glycol-derivatized } \\
\text { capsaicin polymeric prodrug } \\
\text { micellar carrier } \\
\text { (PEG-Fmoc-CAP })\end{array}$ & PTX + Capsaicin (CAP) & Preclinical & $\begin{array}{l}\text { In vitro: synergistic antitumor } \\
\text { efficacy against tumor cell growth } \\
\text { ( } 4 \mathrm{~T} 1 \text { cells); } \\
\text { In vivo: efficient tumor accumulation, } \\
\text { and more effective tumor growth } \\
\text { inhibition. }\end{array}$ & (Lan et al., 2019) \\
\hline $\begin{array}{l}\text { Noscapine-Loaded Polymeric } \\
\text { Nanoparticles and doxorubicin }\end{array}$ & DOX + Noscapine (NOS) & Preclinical & $\begin{array}{l}\text { In vitro: synergistic anticancer effects } \\
\text { of DOX and NOS in } 4 \mathrm{~T} 1 \text { cells; } \\
\text { In vivo: antiangiogenic and apoptotic } \\
\text { effects on tumor tissue, which } \\
\text { enhanced in combination with DOX. }\end{array}$ & (Esnaashari et al., 2020) \\
\hline $\begin{array}{l}\text { Polymeric prodrug-based } \\
\text { nanomedicine delivering } \\
\text { nifuroxazide and doxorubicin } \\
\text { (CLM) }\end{array}$ & DOX + Nifuroxazide (NFX) & Preclinical & $\begin{array}{l}\text { In vitro: reduce viability, inhibit } \\
\text { migration and invasion of } 4 \mathrm{~T} 1 \text { murine } \\
\text { breast cancer cells; } \\
\text { In vivo: CLM significantly } \\
\text { suppressed growth of the tumor in } \\
\text { mammary via i.v. injection every } 4 \\
\text { days for } 5 \text { times. }\end{array}$ & (Luo et al., 2020) \\
\hline
\end{tabular}

Source: Authors (2021) 


\section{Perspectives on the use of Nanotechnology in Drug Combination}

Anti-cancer drugs have variable efficacy within patient populations, but when different drugs are combined, patients can benefit from the mechanism of different compounds, which can enhance therapeutic efficacy (Palmer \& Sorger, 2017). Clinical cancer treatment can be combined with multidrug to improve efficacy of treatments and avoid resistance mechanisms like over-expression of pump out drugs or anti-apoptotic proteins (Devita Jr et al., 1975). There are some drug combinations that are superior to only one drug administration. For example, monotherapies with some cancers reach few or even any cures, but drug combination cure rates, can reach $80 \%$ (Frei, 1985). This may be due to the synergistic effect of the drugs or even independent mechanisms (Swain et al., 2015).

One of the causes of the drug resistance mechanism is the overexpression of drug efflux like ATP-binding cassette (ABC) transporters that pump the drug out of the cell, thus decreasing the effective concentration of the therapeutic agent. The P-glycoprotein transporter, for example, an ATP-driven efflux pump, is overexpressed in some types of cancers (Gottesman, 2002; X. Li et al., 2008). Over-expression of NF-kB also is related to drug resistance, because these nuclear factors produce antiapoptotic proteins (Patel et al., 2000).

The use of combination of drugs in nanoparticles can be an excellent strategy with some types of cancer that are resistant to treatments (Hu \& Zhang, 2012). Nanoparticles can be a great alternative against that resistance due the different mechanism of action and therapeutic drugs (HU et al., 2012). For instance, nanoemulsions with curcumin can block multidrug transporters,inhibit NF-kB and also have been co-delivered with chemotherapeutics (Ganta \& Amiji, 2009; Hu \& Zhang, 2012; Misra \& Sahoo, 2011).

More recently, Franco and co-authors (2019), reported a study using Balb/c mice with murine breast carcinoma (4T1). Development of a nanotechnological approach in the development of lipid nanosystems, especially liposomes, as carriers of cytotoxic drugs already used in the clinic, aiming at increasing therapeutic efficacy and reducing / eliminating adverse effects. Main finding in which demonstrates that the addition of small amounts of the drug PTX combined with DOX (molar ratio 1:10, respectively) is sufficient for a response in the treatment activity, comparing the free form of both drugs. In addition, an interesting response was the decrease in cardiac toxicity compared to treatment with the free combination of the compound (Franco et al., 2019).

An advanced approach in relation to the combination of drugs can be observed in the work of Lima et al, 2020, where the authors used two classic cytotoxic drugs PTX and DOX transported in a single nanostructured system (liposomes - LipoPacli / Dox), against a metastatic breast cancer model. The highlight of the article was that treatment with the Lipo-Pacli / Dox system was able to reverse the tolerogenic environment of metastatic lesions through a positive correlation between lymphocyte infiltrate and the control of metastasis progression. In addition, the encapsulation of the combined drugs has been shown to be able to significantly reduce the systemic toxicity of these chemotherapeutic agents after administration when nanotechnological platform where two drugs combined in a single carrier can lead (de Lima et al., 2020).

\section{Conclusion}

It is possible to use different chemotherapeutic agents in combination to improve the therapeutic efficacy in various types of cancer, including breast cancer. Also, the chemotherapeutic agents need to be selected to drive maximum benefit of all drugs, as a synergic or additive effect. Moreover, the toxicity of the drugs must be taken into account so that there is no increase in adverse effects. The use of nanoparticles as delivery to combination therapy shows great benefits to breast cancer patients. Aspects of improved efficacy, decreased or controlled toxicity, besides the possibility of avoiding the cell resistance mechanisms. However, future studies are needed to understand the safety of combining two drugs and choosing the best carrier. 


\section{Acknowledgements}

We thank the Department of Genetics and Morphology, Institute of Biological Sciences, University of Brasilia (GEMIB-UnB) for their kind support in providing resources and infrastructure for the study. This work did not receive any specific support, but we would like to thank the funding agencies: the Brazilian National Council for Technological and Scientific Development (CNPq), Coordinating Agency for Advanced Training of Graduate Personnel (CAPES), Foundation for Research Support of the Federal District (FAPDF) an the Dean of Research and Post-Graduation of the University of Brasilia (DPP-UnB).

\section{References}

Al-Lazikani, B., Banerji, U., \& Workman, P. (2012). Combinatorial drug therapy for cancer in the post-genomic era. Nature Biotechnology, 30(7), 679-692.

Al-Mahayri, Z. N., Patrinos, G. P., \& Ali, B. R. (2020). Toxicity and Pharmacogenomic Biomarkers in Breast Cancer Chemotherapy. Frontiers in Pharmacology, 11,445 .

Aulic, S., Marson, D., Laurini, E., Fermeglia, M., \& Pricl, S. (2020). Breast cancer nanomedicine market update and other industrial perspectives of nanomedicine. In Nanomedicines for Breast Cancer Theranostics (pp. 371-404). Elsevier.

Barzaman, K., Karami, J., Zarei, Z., Hosseinzadeh, A., Kazemi, M. H., Moradi-Kalbolandi, S., Safari, E., \& Farahmand, L. (2020). Breast cancer: Biology, biomarkers, and treatments. International Immunopharmacology, 84, 106535.

Beltrán-Gracia, E., López-Camacho, A., Higuera-Ciapara, I., Velázquez-Fernández, J. B., \& Vallejo-Cardona, A. A. (2019). Nanomedicine review: clinical developments in liposomal applications. Cancer Nanotechnology, 10(1), 11.

Bobo, D., Robinson, K. J., Islam, J., Thurecht, K. J., \& Corrie, S. R. (2016). Nanoparticle-based medicines: a review of FDA-approved materials and clinical trials to date. Pharmaceutical Research, 33(10), 2373-2387.

Bonadonna, G., Brusamolino, E., Valagussa, P., Rossi, A., Brugnatelli, L., Brambilla, C., De Lena, M., Tancini, G., Bajetta, E., Musumeci, R., \& others. (1976). Combination chemotherapy as an adjuvant treatment in operable breast cancer. New England Journal of Medicine, 294(8), 405-410.

Bulbake, U., Doppalapudi, S., Kommineni, N., \& Khan, W. (2017). Liposomal formulations in clinical use: an updated review. Pharmaceutics, 9(2), 12.

Cooper, R. G. (1969). Combination chemotherapy in hormone resistant breast cancer. Proceedings of the American Association for Cancer Research, 10(MAR), 15 .

Correia, A., Silva, D., Correia, A., Vilanova, M., Gärtner, F., \& Vale, N. (2018). Study of new therapeutic strategies to combat breast cancer using drug combinations. Biomolecules, 8(4), 175.

De Cicco, P., Catani, M. V., Gasperi, V., Sibilano, M., Quaglietta, M., \& Savini, I. (2019). Nutrition and breast cancer: a literature review on prevention, treatment and recurrence. Nutrients, 11(7), 1514.

de Lima, L. I., Faria, R. S., Franco, M. S., Roque, M. C., Arruda Pacheco, T. J., Rodrigues, M. C., Muehlmann, L. A., Moya, S. E., Azevedo, R. B., de Oliveira, M. C., \& others. (2020). Combined paclitaxel-doxorubicin liposomal results in positive prognosis with infiltrating lymphocytes in lung metastasis. Nanomedicine, 15(29), 2753-2770.

Devita Jr, V. T., Young, R. C., \& Canellos, G. P. (1975). Combination versus single agent chemotherapy: a review of the basis for selection of drug treatment of cancer. Cancer, 35(1), 98-110.

Di, H., Wu, H., Gao, Y., Li, W., Zou, D., \& Dong, C. (2016). Doxorubicin-and cisplatin-loaded nanostructured lipid carriers for breast cancer combination chemotherapy. Drug Development and Industrial Pharmacy, 42(12), 2038-2043.

Di Wu, M. S., Xue, H.-Y., \& Wong, H.-L. (2017). Nanomedicine applications in the treatment of breast cancer: current state of the art. International Journal of Nanomedicine, 12, 5879 .

Ding, Y., Su, S., Zhang, R., Shao, L., Zhang, Y., Wang, B., Li, Y., Chen, L., Yu, Q., Wu, Y., \& others. (2017). Precision combination therapy for triple negative breast cancer via biomimetic polydopamine polymer core-shell nanostructures. Biomaterials, 113, $243-252$.

Esnaashari, S. S., Muhammadnejad, S., Amanpour, S., \& Amani, A. (2020). A Combinational Approach Towards Treatment of Breast Cancer: an Analysis of Noscapine-Loaded Polymeric Nanoparticles and Doxorubicin. AAPS PharmSciTech, 21, 166.

Espinosa, P. P., \& Espinosa, M. J. (2016). Experiences to chemotherapy among women with breast cancer. Int J Bio Sci Bio Technol, 8, $159-166$.

Fabi, A., Ferretti, G., Malaguti, P., Gasparro, S., Nisticò, C., Arpino, G., Papaldo, P., Russillo, M., Catania, G., Schettin i, F., \& others. (2020). Nanoparticle albumin-bound paclitaxel/liposomal-encapsulated doxorubicin in HER2-negative metastatic breast cancer patients. Future Oncology, 0 .

Falagan-Lotsch, P., Grzincic, E. M., \& Murphy, C. J. (2017). New advances in nanotechnology-based diagnosis and therapeutics for breast cancer: an assessment of active-targeting inorganic nanoplatforms. Bioconjugate Chemistry, 28(1), 135-152.

Fernandes, R. S., Silva, J. O., Seabra, H. A., Oliveira, M. S., Carregal, V. M., Vilela, J. M. C., Andrade, M. S., Townsend, D. M., Colletti, P. M., Leite, E. A., \& others. (2018). \$ $\$$-Tocopherol succinate loaded nano-structed lipid carriers improves antitumor activity of doxorubicin in breast cancer models in vivo. Biomedicine \& Pharmacotherapy, 103, 1348-1354. 
Fisusi, F. A., \& Akala, E. O. (2019). Drug Combinations in Breast Cancer Therapy. Pharmaceutical Nanotechnology, 7(1), 3-23.

Fraguas-Sánchez, A. I., Mart’’in-Sabroso, C., Fernández-Carballido, A., \& Torres-Suárez, A. I. (2019). Current status of nanomedicine in the chemotherapy of breast cancer. Cancer Chemotherapy and Pharmacology, 1-18.

Franco, M. S., Roque, M. C., de Barros, A. L. B., de Oliveira Silva, J., Cassali, G. D., \& Oliveira, M. C. (2019). Investigation of the antitumor activity and toxicity of long-circulating and fusogenic liposomes co-encapsulating paclitaxel and doxorubicin in a murine breast cancer animal model. Biomedicine \& Pharmacotherapy, 109, 1728-1739.

Frei, E. (1985). Curative cancer chemotherapy. Cancer Research, 45(12 Part 1), 6523-6537.

FREI III, E., KARON, M., LEVIN, R. H., Freireich, E. J., TAYlOR, R. J., HANANIAN, J., SELAWRY, O., HOLLAND, J. F., HOOGSTRATEN, B., WOLMAN, I. J., \& others. (1965). The effectiveness of combinations of antileukemic agents in inducing and maintaining remission in children with acute leukemia. Blood, 26(5), 642-656.

Ganta, S., \& Amiji, M. (2009). Coadministration of paclitaxel and curcumin in nanoemulsion formulations to overcome multidrug resistance in tumor cells. Molecular Pharmaceutics, 6(3), 928-939.

Gottesman, M. M. (2002). Mechanisms of cancer drug resistance. Annual Review of Medicine, 53(1), 615-627.

Hu, C.-M. J., \& Zhang, L. (2012). Nanoparticle-based combination therapy toward overcoming drug resistance in cancer. Biochemical Pharmacology, 83(8), 1104-1111.

Kostarelos, K. (2006). The emergence of nanomedicine: a field in the making.

Lan, Y., Sun, Y., Yang, T., Ma, X., Cao, M., Liu, L., Yu, S., Cao, A., \& Liu, Y. (2019). Co-delivery of paclitaxel by a capsaicin prodrug micelle facilitating for combination therapy on breast cancer. Molecular Pharmaceutics, 16(8), 3430-3440.

Li, M., Luo, Z., \& Zhao, Y. (2018). Self-assembled hybrid nanostructures: versatile multifunctional nanoplatforms for cancer diagnosis and therapy. Chemistry of Materials, 30(1), 25-53.

Li, X., Yuan, H., Wu, J., Li, J., Qu, X., Xu, W., \& Tang, W. (2008). Strategies to overcome or circumvent P-glycoprotein mediated multidrug resistance. Current Medicinal Chemistry, 15(5), 470-476.

Li, Z., Tan, S., Li, S., Shen, Q., \& Wang, K. (2017). Cancer drug delivery in the nano era: An overview and perspectives. Oncology Reports, $38(2), 611-624$.

Liyanage, P. Y., Hettiarachchi, S. D., Zhou, Y., Ouhtit, A., Seven, E. S., Oztan, C. Y., Celik, E., \& Leblanc, R. M. (2019). Nanoparticle-mediated targeted drug delivery for breast cancer treatment. Biochimica et Biophysica Acta (BBA)-Reviews on Cancer, 1871(2), 419-433.

Luo, L., Xu, F., Peng, H., Luo, Y., Tian, X., Battaglia, G., Zhang, H., Gong, Q., Gu, Z., \& Luo, K. (2020). Stimuli-responsive polymeric prodrug-based nanomedicine delivering nifuroxazide and doxorubicin against primary breast cancer and pulmonary metastasis. Journal of Controlled Release, 318, $124-135$.

Malhotra, V., \& Perry, M. C. (2003). Classical chemotherapy: mechanisms, toxicities and the therapeutc window. Cancer Biology \& Therapy, 2(sup1), 1-3.

Mignani, S., Bryszewska, M., Klajnert-Maculewicz, B., Zablocka, M., \& Majoral, J.-P. (2015). Advances in combination therapies based on nanoparticles for efficacious cancer treatment: an analytical report. Biomacromolecules, 16(1), 1-27.

Misra, R., \& Sahoo, S. K. (2011). Coformulation of doxorubicin and curcumin in poly (D, L-lactide-co-glycolide) nanoparticles suppresses the development of multidrug resistance in K562 cells. Molecular Pharmaceutics, 8(3), 852-866.

Nguyen, P. L., Gu, X., Lipsitz, S. R., Choueiri, T. K., Choi, W. W., Lei, Y., Hoffman, K. E., \& Hu, J. C. (2011). Cost implic ations of the rapid adoption of newer technologies for treating prostate cancer. Journal of Clinical Oncology, 29(12), 1517.

Özdelikara, A., \& Tan, M. (2017). The effect of reflexology on chemotherapy-induced nausea, vomiting, and fatigue in breast cancer patients. Asia-Pacific Journal of Oncology Nursing, 4(3), 241.

Palmer, A. C., \& Sorger, P. K. (2017). Combination cancer therapy can confer benefit via patient-to-patient variability without drug additivity or synergy. Cell, $171(7), 1678-1691$.

Pan, J., Mendes, L. P., Yao, M., Filipczak, N., Garai, S., Thakur, G. A., Sarisozen, C., \& Torchilin, V. P. (2019). Polyamidoamine dendrimers-based nanomedicine for combination therapy with siRNA and chemotherapeutics to overcome multidrug resistance. European Journal of Pharmaceutics and Biopharmaceutics, 136, 18-28.

Patel, N. M., Nozaki, S., Shortle, N. H., Bhat-Nakshatri, P., Newton, T. R., Rice, S., Gelfanov, V., Boswell, S. H., Goulet, R. J., Sledge, G. W., \& others. (2000).

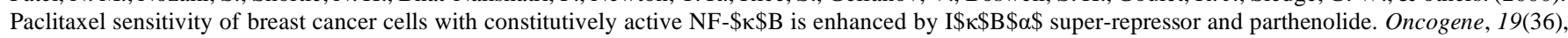
4159-4169.

Rajora, A. K., Ravishankar, D., Zhang, H., \& Rosenholm, J. M. (2020). Recent Advances and Impact of Chemotherapeutic and Antiangiogenic Nanoformulations for Combination Cancer Therapy. Pharmaceutics, 12(6), 592.

Roque, M. C., Franco, M. S., Vilela, J. M. C., Andrade, M. S., de Barros, A. L. B., Leite, E. A., \& Oliveira, M. C. (2019). Development of Long-Circulating and Fusogenic Liposomes Co-encapsulating Paclitaxel and Doxorubicin in Synergistic Ratio for the Treatment of Breast Cancer. Current Drug Delivery, 16(9), 829838 .

Shim, G., Kim, M.-G., Kim, D., Park, J. Y., \& Oh, Y.-K. (2017). Nanoformulation-based sequential combination cancer therapy. Advanced Drug Delivery Reviews, 115, 57-81. 
Society, U. K. R. (2004). Nanoscience and Nanotechnologies: Opportunities and Uncertainties. The Royal Society and The Royal Academy of Engineering London.

Song, M., Liang, Y., Li, K., Zhang, J., Zhang, N., Tian, B., \& Han, J. (2019). Hyaluronic acid modified liposomes for targeted delivery of doxorubicin and paclitaxel to CD44 overexpressing tumor cells with improved dual-drugs synergistic effect. Journal of Drug Delivery Science and Technology, 53 , 101179.

Swain, S. M., Baselga, J., Kim, S.-B., Ro, J., Semiglazov, V., Campone, M., Ciruelos, E., Ferrero, J.-M., Schneeweiss, A., Heeson, S., \& others. (2015). Pertuzumab, trastuzumab, and docetaxel in HER2-positive metastatic breast cancer. New England Journal of Medicine, 372(8), 724-734.

Tang, H., Chen, J., Wang, L., Li, Q., Yang, Y., Lv, Z., Bao, H., Li, Y., Luan, X., Li, Y., \& others. (2020). Co-delivery of epirubicin and paclitaxel using an estrone-targeted PEGylated liposomal nanoparticle for breast cancer. International Journal of Pharmaceutics, $573,118806$.

Tran, P., Lee, S.-E., Kim, D.-H., Pyo, Y.-C., \& Park, J.-S. (2020). Recent advances of nanotechnology for the delivery of anticancer drugs for breast cancer treatment. Journal of Pharmaceutical Investigation, 50(3), 261-270.

Ventola, C. L. (2017). Progress in nanomedicine: approved and investigational nanodrugs. Pharmacy and Therapeutics, $42(12), 742$.

Wolfram, J., \& Ferrari, M. (2019). Clinical cancer nanomedicine. Nano Today, 25, 85-98.

Wu, D., Pusuluri, A., Vogus, D., Krishnan, V., Shields IV, C. W., Kim, J., Razmi, A., \& Mitragotri, S. (2020). Design principles of drug combinations for chemotherapy. Journal of Controlled Release.

You, Y.-H., Lin, Y.-F., Nirosha, B., Chang, H.-T., \& Huang, Y.-F. (2019). Polydopamine-coated gold nanostar for combined antitumor and antiangiogenic therapy in multidrug-resistant breast cancer. Nanotheranostics, 3(3), 266.

Zeinali, M., Abbaspour-Ravasjani, S., Ghorbani, M., Babazadeh, A., Soltanfam, T., Santos, A. C., Hamishehkar, H., \& Hamblin, M. R. (2020). Nanovehicles for co-delivery of anticancer agents. Drug Discovery Today.

Zhang, J., Zhang, P., Zou, Q., Li, X., Fu, J., Luo, Y., Liang, X., \& Jin, Y. (2018). Co-delivery of gemcitabine and paclitaxel in CRGD-modified long circulating nanoparticles with asymmetric lipid layers for breast cancer treatment. Molecules, 23(11), 2906. 